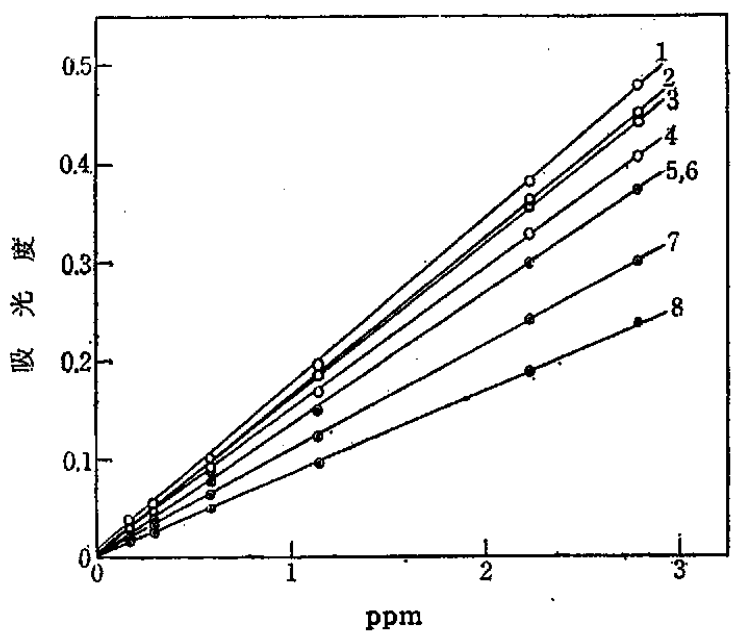

O: $260 \mathrm{~m} \mu, \odot: 300 \mathrm{~m} \mu, p \mathrm{H} 3.00$

1: Fe.DTPA,

3: Fe.CyDTA,

$5: \mathrm{Fe} \cdot \mathrm{DTPA}$,

$7: \mathrm{Fe} \cdot \mathrm{CyDTA}$,

2: $\mathrm{Fe} \cdot \mathrm{GEDTA}$

4: Fe.EDTAOH

6: Fe.GEDTA

8: $\mathrm{Fe} \cdot \mathrm{EDTAOH}$

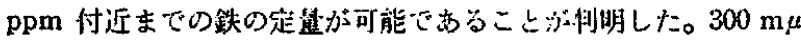
以上では DTPA, GEDTA， CyDTA 錯体ではEDA 錯体上 りも吸光度が大きい。 $260 \mathrm{~m} \mu$ での妨害イオンは銅(I)，ビスマ ス(I)，鉛(I)，ウラン(V)，バナジウム(V)，マンガン(I)， 水銀（I）抢よびカドミウムなどであるが， $300 \mathrm{~m} \mu$ ではマンガン の DTPA, GEDTA 鍇体, 鉛㧍よび水銀の DTPA, GEDTA, EDTA.OH 錯体には吸取がない。ビスマス锴体は $320 \mathrm{~m} \mu$ こ吸 収がなくなる。したがって $330 \mathrm{~m} \mu$ あるいは $320 \mathrm{~m} \mu$ の波長こ吸 取を示すのは銈（I），ウラン(U)，バナシウム(V)なよ゙である。 $260 \mathrm{~m} \mu$ で吸收家すこれらの錯体については引きつつき報告す る羊である。

䄸を終るにのぞみ，本研究な行なうにあたり終始衙琶切な御

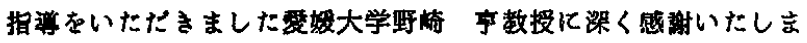
す。一方，本研究費の一部は文部省科学矿究䠝によったととな付 㫜して感謝の䓯を表します。

（1963 年 11 月，日本化学会中国四国吝部地方大会撛演）

图 9 検 量 線

\title{
1, 1,2-トリクロルェタンを抽出溶媒とした微量アルキルベンゼンスルホン酸塭の吸光光度定量
}

(昭和 39 年 3 月 7 日受理)

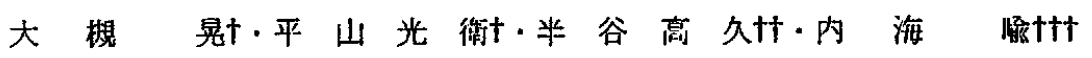

水中に存在する微量のアルキルベンゼンスルホン酸塩の吸光光度定量については多くの方法が提案さ机ているが，一般に感度が 低く，また防害物霓の除去などに問題があり，迅速かつ简易な满足すべき定量法はまた報告されていない。

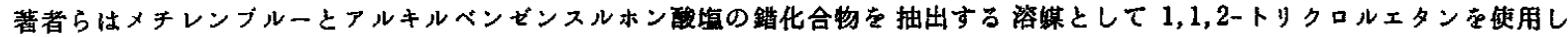

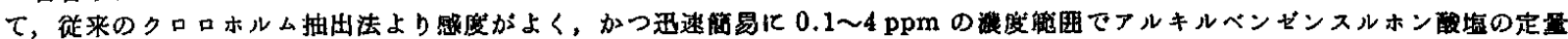

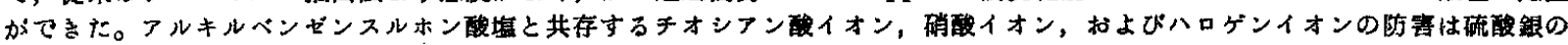

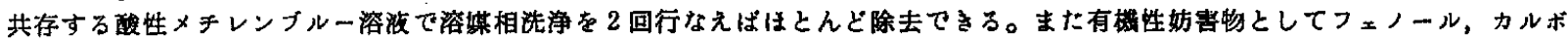

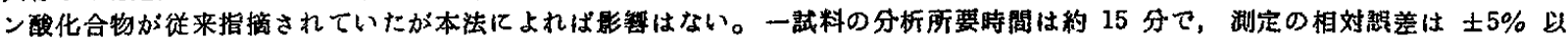
内である。

\section{1 緒 岩}

アルキルベンゼンスルホン酸ナトリウム(以下ABSと略記する) はもっとも一般的に使用さ机ている合成洗削の一つである。この ABS は水中で安定で，嫌気的，好気的条件化あっても微生物に より簢単には分解されず，河川水中に残存するため水質污染の立 場加ら問題になっている。

水中に存在する微量の ABS の分析法の検討はかなり広く行な わ扎ているが，迅速かつ簡易な方法は Skougstad らリが述べて いるようにまだ完成されていない。

既存の分析法を大別すると, メチレンブルー法2)ー4)と赤外蚁収

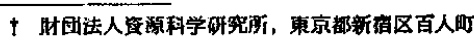

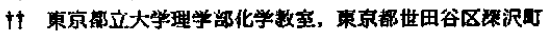

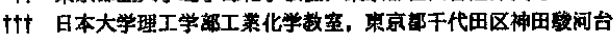

1) M. W. Shougstad, M. J. Fishman, Anal. Chem. 35, Anual Reviews 193R(1963).

2) J. H. Jones, J. Assoc. Offic. Agr. Chemists 26, 945(1945).

3) H. C. Evans, J. Soc. Chem. Ind. Bs, S76(1950).

4) P. N. Degens, H. C. Evans, J. D. Kommer, P. A. Winsor, $J$. Appl. Chem. 3, 54(1953).
スペクトル法らけにわけられる。前者は酸性溶湤でメチレンブル 一と ABSの錯化合物を生成させ,これをク口ロホルムで抽出し て波長 650〜652 $\mathrm{m} \mu$ で财光度芳測定し定量する方法でかり，ア メリカに抢いては楾淮分析法》として採用されている。後者は ABS 活性炭に吸着させ，つぎにアルカり性ベンゼン・メタ， 一ル溶媒系で ABS を眖举し，波長 9.6 および $9.9 \mathrm{~m} \mu$ の樶収 から定量する方法で，正確な測定值を与えるといわれているが， 操作が䫅雑で分析に長時間を要するのが大きな欠点である。メチ レンブルー法の欠点は，クロロホルムによる銷化会物の抽出力が 小さく、ふりまぜ抽出を 3 回も行なわなくてはならないとと，末 た感度も低く，共存する物質の妨㮫も少なくないことである。

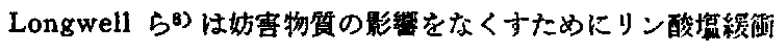
溶液で $p \mathrm{H} 10$ Kたもちメチレンブルーの中性溶液を加えク口ロ

5) E. M. Sallee, et al., Anal. Chem. 28, 1822(1956).

6) C. P. Ogden, H. L. Webster, J. Hatliday, Analy'st 86, 22(1961).

7) APHA - AWWA - WPCF, "Standard Method for the Ex. amination of Water and Waste" (1960) p. 246

8) J. Longwell, W. D. Mansece, Analy'st 10, 167(1955). 


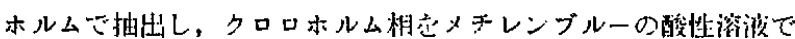

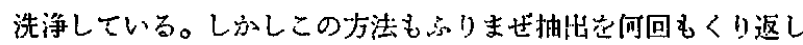
ているので，長洔問定要し感度も低い。

Hill ら゚はクロム硫酸処理觉提案しているが前処理だけで約 1 時間以上も要する。内海ら103はメチレンブルー・ABS 錯化合物 の抽出溶媒こして 1,2-シクロルエタン觉推琶している。

著者らはシクロルエタンより水に対する浴解度が小さく，かつ 蒸気压の低い1，1，2-トリクロルエタンを抽出浴媒しして使用し

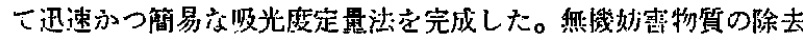
に注硫酸銀共存の溶媒相洗浄学用いて漼媒相洗浄岁行ない，水中 の微量 ABS 0.1 4 ppm の範围で再現性よく定量できた。 一試料の分析時間は的 15 分である。

\section{2 実醶}

\section{1 尌菜}

2.1.1 DSB 標準溶液: ABS 中の標準物質として $n$-ドデシル ベンゼンスルホン酸ナトリウム(以下 DBS と略記する)を採网し， 東京化成彆の 1 級試薬(純度 95.6\%)をそのまま使用した。1000 $\mathrm{ppm}$ 溶漼定調製し，実駼に際し適宜希积して用いた。

2.1.2 メチレンブルー溶浓：Merk 製のメチレンブルー $\left(\mathrm{C}_{16}\right.$. $\left.\mathrm{H}_{18} \mathrm{~N}_{3} \mathrm{SCl} \cdot 3 \mathrm{H}_{2} \mathrm{O}\right)$ 定使用し， $0.15 \%(\mathrm{w} / \mathrm{v})$ 溶液さつくり，裀色ビ ンに保存し適宜 $0.015 \%$ 溶液 $\left(4.0 \times 10^{-4} \mathrm{~mol}\right)$ に荞积して用いた。 この溶液は 2 䈏月経過しても安定であった。

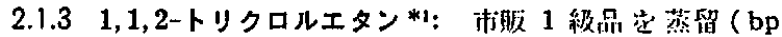
$113.5^{\circ} \sim 114.5^{\circ} \mathrm{C}$ )して使用した。

2.1 .4 溶媒相洗浄溶液：メチレンブルー $0.13 \mathrm{~g}$ 䘮，滥硫酸 1.2 $\mathrm{m} l$ 亡蒸留水 $50 \mathrm{~m} l$ の溶湤に加え $100 \mathrm{~m} l$ とすう。この溶液赏 $10 \mathrm{~m} l$ 取り，硫酸銀 $0.22 \mathrm{~g}$ を加えて $1 l$ として洗浮溶液とした。

$2.1 .50 .1 \mathrm{~N}$ 硫酸溶液：特級品究用い調製した。

2.1.6 その他：之の他無機，有機試藥はすべて市䛀の最高級品 をそのまま使用した。

\section{2 装}

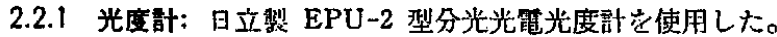
吸取セルは $10 \mathrm{~mm}$ のものて使用した。

2.2.2 フリマセ器：使用したフリマゼ器はイワキ製 $\mathrm{KM}$ 型で, ふりませ速度は每分 300 回，振憎は $4 \mathrm{~cm}$ である。

\section{3 定旦提作および検量線}

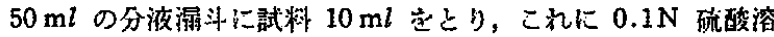
液 $0.5 \mathrm{ml}$ 加え，さらに $0.015 \%$ ×レンブルー溶液を $1 \mathrm{ml}$ 加える。ついで 1,1,2-トリクロルエタンを $10 \mathrm{~m} l$ 加えてフリマ ゼ器て 40 秒間ふりまぜる。水溶液相と溶媒相が分離したのち,

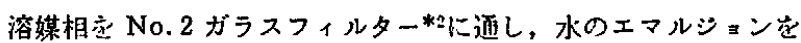
除去する。この透明な青色溶液を $10 \mathrm{~mm}$ のガラスセル使用し， 1,1,2-トリクロルエタンを対照液として波長 $655 \mathrm{~m} \mu$ で吸光度を 測定し㭘量線から定量する。本操作は内海ら10)のシクロルエタン 抽出法の定量操作とほぼ同じである。この操作で得られた検量線 额1に示吉。

9) W. H. Hill, M. A. Shapiro, Y. Kobayashi, J. Am. Water Works Assoc. 54, 409(1962).

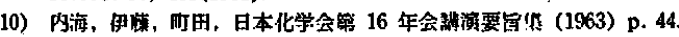

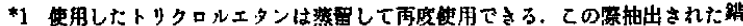

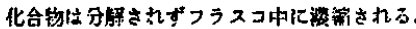

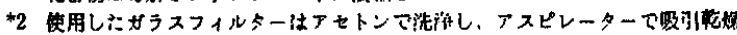
してたな゙ちに戡用でる。

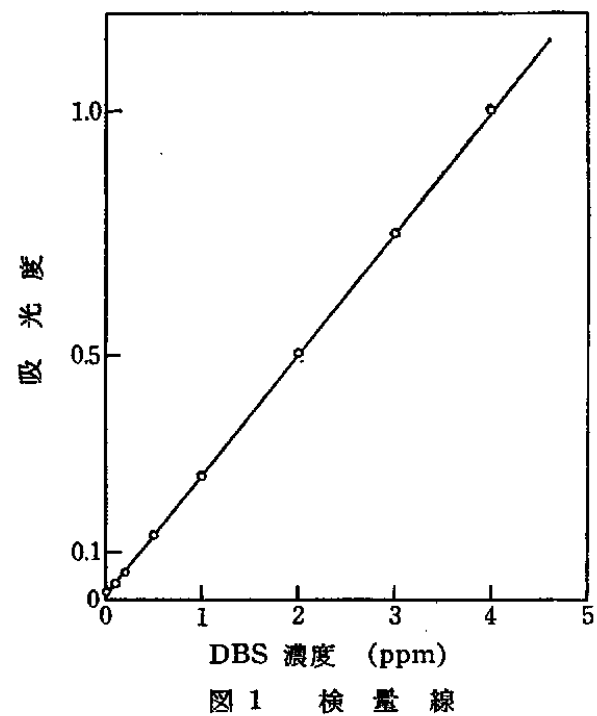

\section{3 定量法の検討および考察}

\section{1 メチレンブルーと DBS 錯化合物の組成}

2.3 で述べた条件で生成されるメチレンブルーとDBS の錯化 合物の組成を決定するため以下に記す赛験崖行なった。

$4.0 \times 10^{-5} \mathrm{~mol} \times$ ×レンブルー溶液を調製し， $50 \mathrm{ml}$ 分液漏斗 に $10 \mathrm{ml}$ とる。ついで $0.1 \mathrm{~N}$ 硫酸溶液 $0.5 \mathrm{~m} l$, およびトリク口 ルエタン $10 \mathrm{ml}$ を加えて, $2.88 \times 10^{-5} \mathrm{~mol}$ DBS 溶液 $(10 \mathrm{ppm})$

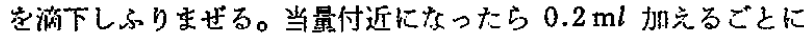
ふりまぜ，水溶液の青色が消充るとこ万を終点とする。

得られた結果注明らかにメチレンブルーと DBS 1: 1 の制 合で錯化合物究つくっていることがわかった。なお内海ら ${ }^{30} は$ は速 続変化法で縕成究決めジクロルエタン抽出法でる $1: 1$ であると 满演している。

メチレンブルー溶液は硫酸銀を添加しても嵒化銀の沈殿穵生じ ないことから，メチレンブルーは水溶液中ではほとえど解蜼して いないことがかかる。メチレンブルーと硫酸銀が共存する溶液 に過剩の DBS 溶液を添加すると青色透明な溶液は白濁してく る。生成した錯化合物を有機溶媒中に抽出すると水溶液相之溶媒 相の界面に白色の沈殿物が沈降する。この沈殿物に日光岕当てる と褐色に变色する。したがってこの沈殿物は程化銀の沈殿である ことからメチンンブルーとDBS の反応式はつぎのように書くこ とができると考える。

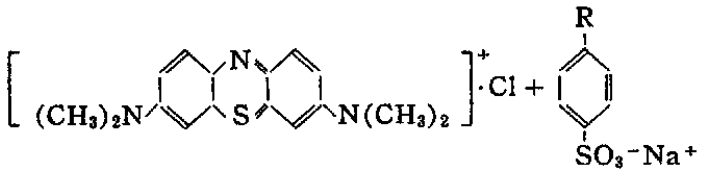

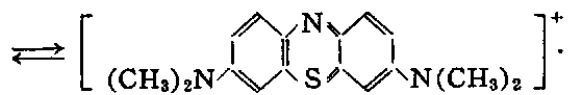

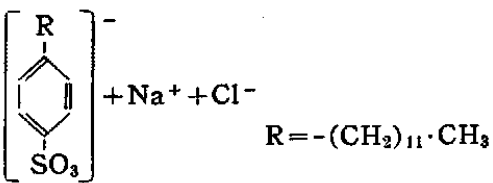

3.2 吸収スペクトル

メチレンプルーと DBS の鍇化合物のトリクロルメタン溶媒中 に打㤝る吸収曲線它図 2 に示す。波長 $654 \mathrm{~m} \mu$ に吸収極大をむっ 


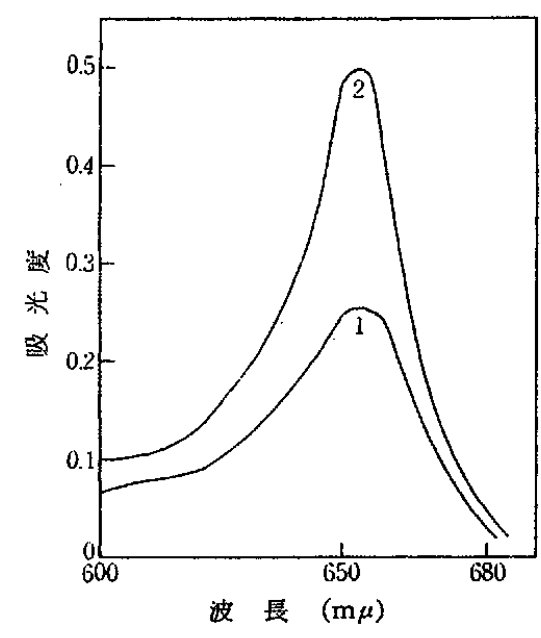

図中の数字は ppm 宗す.

図 2 财収スペクトル

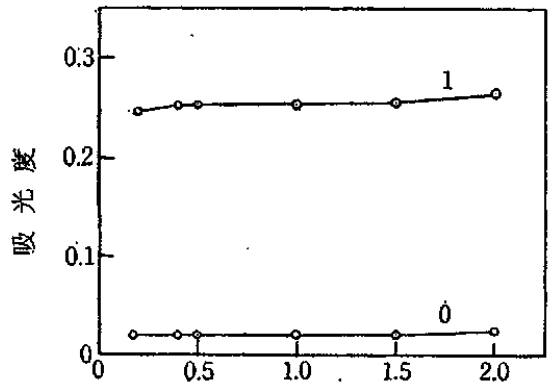

$0.015 \%$ メチレンブルー溶㒈添加量 $(\mathrm{ml})$

図中の数宇は ppm を示す。

柔件: $0.1 \mathrm{~N}$ 硫酸 $0.5 \mathrm{ml}$, 溶媒 $10 \mathrm{ml}$ 抽出時間 40 秒閵

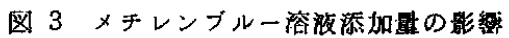

ている。×チレンブルーはトリクロルエタンにはきわめて溶けに くい。

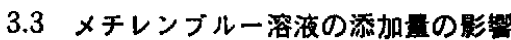

ブランク溶液および DBS $1 \mathrm{ppm}$ 溶液について, メチレンブ

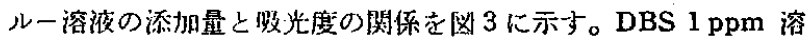
湤ではメチレンブルー溶液が $1 \mathrm{ml}$ 以上，すなわち溶液中浱度が $3.5 \times 10^{-5} \mathrm{~mol}$ 以上であればほほ一定の吸光度を示吉。しかしブ

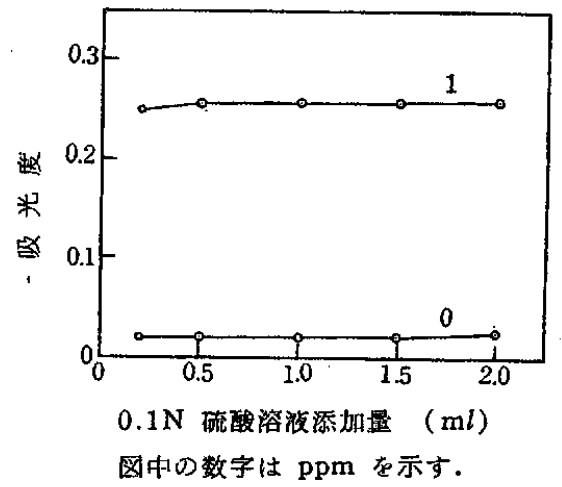

条件: $0.015 \%$ メチレンブルー溶液 $1 \mathrm{~m} l$, 溶媒 $10 \mathrm{ml}$, 抽出時間 40 秒間

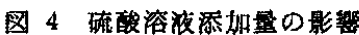

ランク溶液の财光度はメチレンブルー溶液の添加量が增加士ると わずかであるが大きくなる傾网がある。以上の結果亦らして本寒 䮖ではメチレンブルー溶液 $1 \mathrm{~m} l$ を帆いることにした。

\section{4 硫酸溶液の添加量の影望}

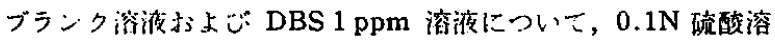

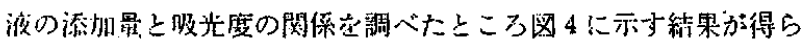

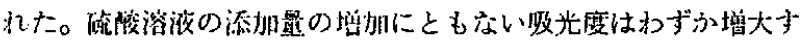
る汸 $0.5 \mathrm{ml}$ 以上の添加ではほぼ一定做示した。ブランク溶液 の股光度も磁酸溶漼の添加量の增加にしたがいわずかであるが増

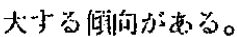

\section{5 䏜光度の経時変化}

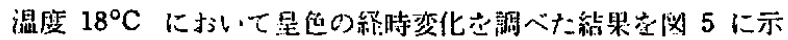

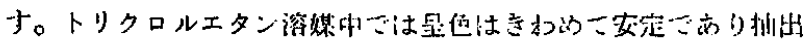

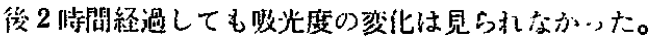

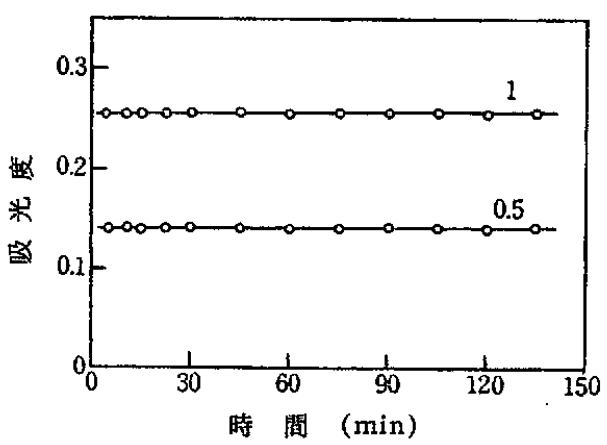

四中の数字は ppm を宗す。

図 5 量色の安定性 (混度 $18^{\circ} \mathrm{C}$ )

\section{6 温度の影䇾}

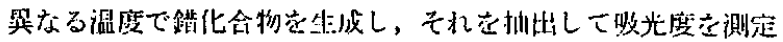
した維果を图6に示す。四6に見られるように湼卧の变化に対す

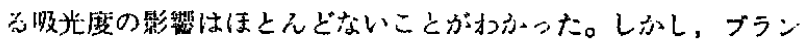

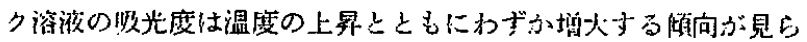
れた。

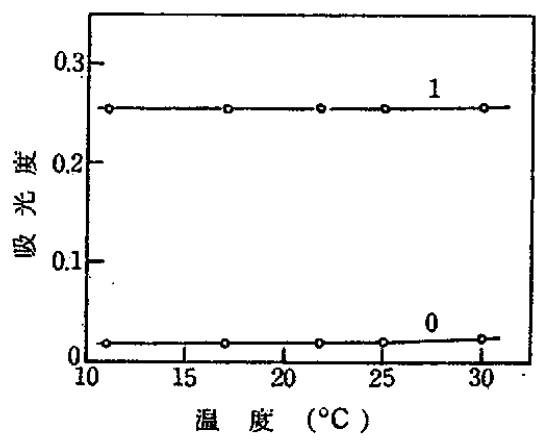

図中の数字は $\mathrm{ppm}$ 杂示す。

図6 䏜光度に扰よ任す温度の影望

\section{7 抽出時間の模討}

2.3 の操作で生成した奮化合物のトリクロルエタンに上る抽出

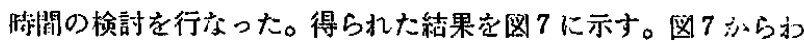
かるように 30 秒間フリマゼ器で抽出壳行なうと收光度はほほ一 定值を得るが，本実駼では 40 秒間岩安全のため採用した。乎で

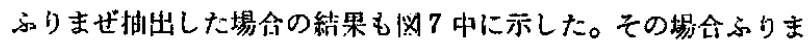
ぜ速度は毎分約 200 回程度でフリマゼ器のそれよりかなり避いた 


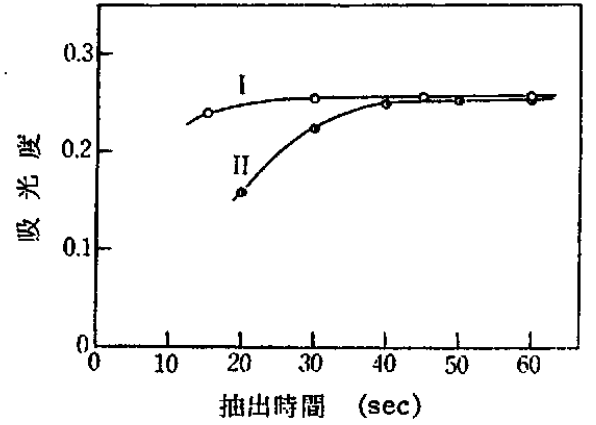

I：フリマゼ器抽出， I：手でるりまぜ抽仙

图 7 政光度上抽出時間の関係

ら图7に示すような絬果分得られたと考えられる。したがって乎 でふりまぜる場合はふりまぜ洔間は1 分間がよい。

\section{8 トリクロルエタンによる錯化合物の抽出回数の检幜}

2.3 の㨘作て鋯化合物空生成し，10 ml の溶媒で抽出回数の检 討艺行なった。得られた結果岕图 8 に示す。图 8 からかかるよう に1回のふりりぜで吸光度として $96 \%$ 以上抽出されることがわ かった。そこで本実験では抽出回数を 1 回とした。

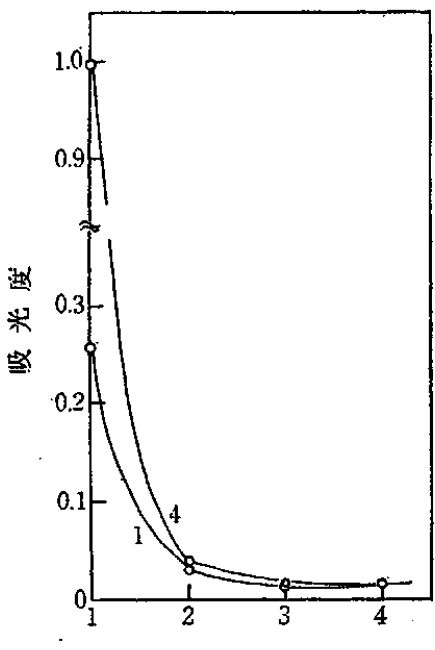

抽出回数

図中の数字は ppm 定示す。

图 8 吸光度乞抽出回数の関係

\section{9 妨害物籍}

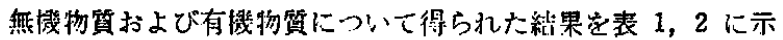

$$
\text { 表 } 1 \text { 妨㫪イオンの影签 }
$$

\begin{tabular}{|c|c|c|c|c|c|}
\hline \multirow[t]{2}{*}{ イオン } & \multirow{2}{*}{$\begin{array}{l}\text { 添加さ } \\
\text { 机た形 }\end{array}$} & \multirow{2}{*}{ 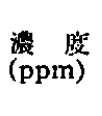 } & \multirow{2}{*}{ 吸光度 } & \multicolumn{2}{|c|}{$\begin{array}{l}\text { 努害イオンの除去 } \\
\text { 溶相洗浄回数 }\end{array}$} \\
\hline & & & & 1 回 & 2 回 \\
\hline- & - & - & 0.021 & 0.021 & 0.020 \\
\hline \multirow[t]{2}{*}{$\mathrm{Cl}^{-}$} & $\mathrm{NaCl}$ & 100 & 0.062 & 0.035 & 0.020 \\
\hline & & 1000 & 0.157 & 0.090 & 0.022 \\
\hline $\mathrm{Br}^{-}$ & $\mathrm{KBr}$ & 10 & 0.113 & 0.047 & - \\
\hline \multirow[t]{3}{*}{$\mathrm{NO}_{3}-$} & $\mathrm{KNO}_{3}$ & 1 & 0.061 & 0.035 & 0.022 \\
\hline & & 5 & 0.195 & 0.058 & 0.027 \\
\hline & & 10 & 0.296 & 0.082 & 0.032 \\
\hline $\mathrm{NO}_{2}-$ & $\mathrm{NaNO}_{2}$ & 20 & 0.104 & 0.043 & - \\
\hline $\mathrm{SCN}^{-}$ & $\mathrm{KSCN}$ & 1 & 0.517 & 0.318 & 0.270 \\
\hline
\end{tabular}

注 a) 2.1.4 の溶某相洗浄液とメチレンブルー扰よび䟽酸淟 度は同しであるが，硫酸銀が北存していない。

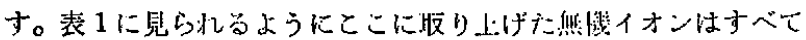
プラスの影整完与充ることがわ和る。とくにチオシアン酸イオン と硙酸イオンのそれは大き。

表 2 に示したようにここで取り上げたベンゼン誘導体に打いて は，スルオン酸基を有するものがすべてメチレンブルーと製化合

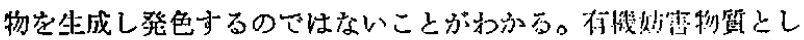
てフェノールラ战よびカルボン陵化合物すが指摘されているが本 法においてはそれらは妨韾物質とならないよらで亦る。

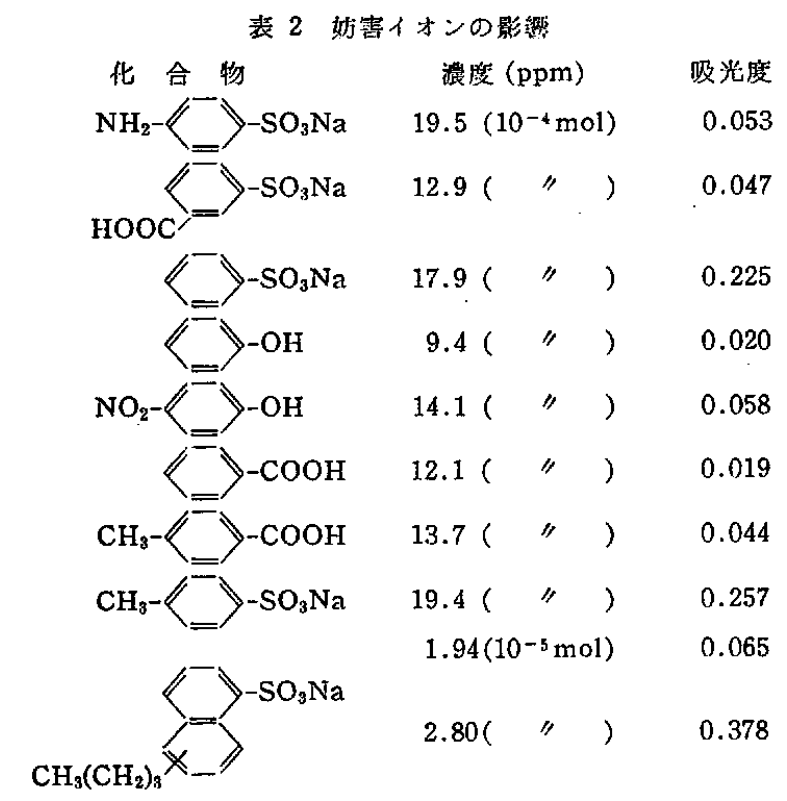

メチレンブルーとチオシアン酸イオン，トルエンスルホン酸, およびブチルナフタリンスルホン酸との錯化命物の吸收曲線定示 すと図9のように店る。吸呮曲線はすべて類似しており波長 654 $\mathrm{m} \mu$ に吸収極大岕もっている。ブチルナフタリンスルホン酸のよ うな大きな分子がメチレンブルーに結合してむ吸収曲線は変化し ない。ベンゼンスルホン酸とトルエンスルホン酸のメチレンブル 一に上る発色の度合はほぼ同じで，DBS にくらべて図1に示す 上うに数十分の一である。ブチルナフタリンスルホン酸の登色の

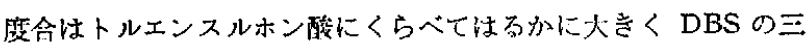
分の一である。Epton"1)はアルキル硫陵塯尤よびアルキルスルホ

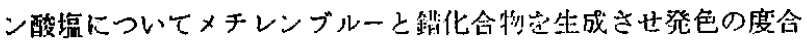
穵調べている。それによるとアルキル楽の岸索数が 8 以上であれ ば十分発色するが炭素数が 7 以下で恃発色の度合が低くなると述 ベている。 ABS およびアルキルナフタリンスルホン酸に拟て る鎖長の炭素数が減少すると発色の度命は小さくなるようであ え。

以上の䋨果から水質調查ではとくにチオシアン酸イオン，碳酸 イオン，堛素イオンの除去が必要であう。

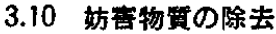

有瀻溶媒中のメチレンブルーとDBS の維化合物性酸性メチレ ンブルー溶液で溶媒相洗浄を行なってすまったく除去され交い。 したがって無機イオンの妨害除志には溶媒相洗浄空採用した*3。 表 $1 ， 3$ に見られるようにチオシアン酸イオン学除き，他のイオ

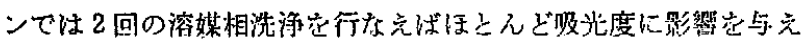

11) S. R. Epton, Trans. Faraday Soc, 44, 226(1948).

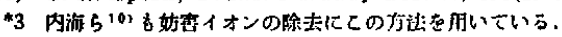




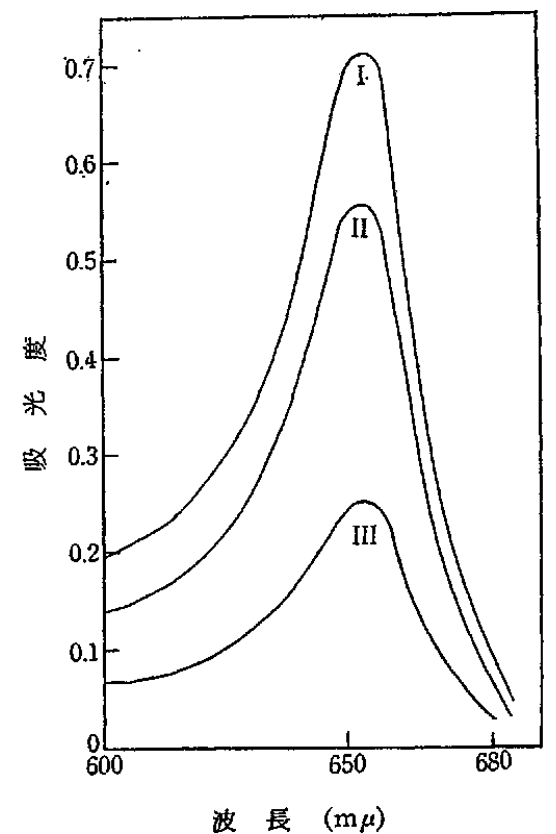

I： nーブチルナフタリンスルホン酸塩との錯化合物

I：チオシアン酸イオンとの鍇化合物

II : トルェンスルホン酸塩との錯化合物

図 9 忣収スペクトル

\section{表 3 其存妨害イオンの影樂}

\begin{tabular}{|c|c|c|c|c|c|c|}
\hline \multirow{2}{*}{$\underset{(\mathrm{ppm})}{\mathrm{DBS}}$} & \multicolumn{3}{|c|}{ 共存イオン（ppm) } & \multicolumn{3}{|c|}{$\begin{array}{l}\text { 共存妨害イオンの除 } \\
\text { 溶媒相洗浄回数 }\end{array}$} \\
\hline & $\mathrm{Cl}^{-}$ & $\mathrm{NO}_{3}{ }^{-}$ & $\mathrm{SCN}^{-}$ & & 1 回 & 2 回 \\
\hline 1 & 0 & 0 & 0 & 0.255 & 0.256 & 0.255 \\
\hline 1 & 0 & 1 & 0 & 0.294 & 0.272 & 0.261 \\
\hline$i$ & 0 & 5 & 0 & 0.352 & 0.282 & 0.260 \\
\hline 1 & 0 & 10 & 0 & 0.449 & 0.291 & 0.263 \\
\hline 1 & 0 & 0 & 1 & 0.558 & 0.394 & 0.388 \\
\hline 1 & 100 & 0 & 0 & 0.308 & 0.287 & 0.272 \\
\hline 1 & 100 & 10 & 0 & 0.458 & 0.310 & 0.260 \\
\hline 1 & 100 & 10 & 1 & $>1.2$ & 0.512 & 0.442 \\
\hline
\end{tabular}

注 $\quad$ ） 2.1 .4 の溶媒相洗浄液とメチレンブルー枪よび硫酸港

ない。硝酸イオンの洗浄效果を図 10 に示す。

チオシアン酸イオンの妨害の除去には，マスキング绪として硫 酸銀溶液を最初に試料に添加する方法と溶媒相洗浄液中に硫酸銀 を共存させ溶媒相洗浄の際に除去する方法を検討し表 4 に示す結 果が得られた。両法の差は明確に現われなかったがともにチオシ 度は凮しであるが硫酸銀が共存していない。

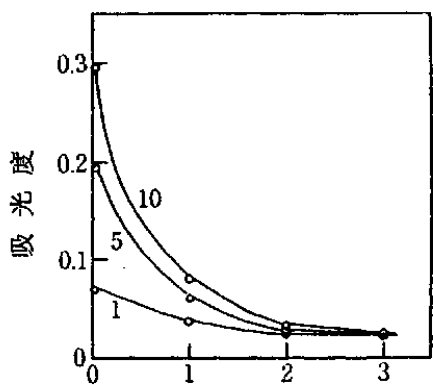

溶媒相洗浄回数

図中の数字は $\mathrm{ppm}$ 示す。

図 10 溶媒相洗浄による硝酸イオンの洗浄効果

アン酸イオンの妨害をほとんど除去できることがわかった。しか し前者は多量に塩素イオンを含有する試料の場合，硫酸銀によっ て生じた壏化銀の沈殿に ABS が共沈りするおうれがある。した がって本法としては硫酸銀を溶媒相洗浄液中に共存させ 2 回洗浄 トることにした。

\subsection{1 妨富イオンが共存する堨合の定量探作}

\section{上記の実験からつぎの定量操作を決定した。}

$50 \mathrm{ml}$ 分液漏斗に試料 $10 \mathrm{ml}$ をとり，これに $0.1 \mathrm{~N}$ 酼酸溶波 $0.5 \mathrm{ml}, 0.015 \%$ ×チレンブルー溶液 $1 \mathrm{ml}$ を加え, さらに 1,1 , 2-トリクロルエタンを $10 \mathrm{ml}$ 加えてフリマゼ器で 40 秒間ふりま 迆る。水溶液相と溶媒相が分蜼したのち，コマゴメピペットで水 溶液相を分液漏斗加らほほ取り除き，硫酸銀共存洗浄溶谯学 10

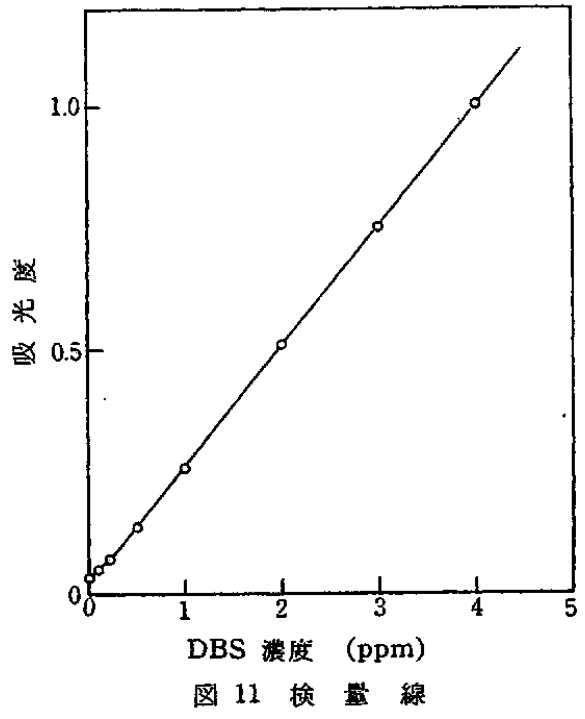

表 4 チオシアン酸イオンの除去 (ppm)

$\begin{array}{lrrr}0 & 0 & 0 & 0 \\ 0.5 & 0 & 0 & 0 \\ 1.0 & 0 & 0 & 0 \\ 0 & 0 & 0 & 1 \\ 1 & 0 & 0 & 1 \\ 0 & 100 & 10 & 1 \\ 0.0 & 100 & 10 & 1 \\ 1.0 & 100 & 10 & 1\end{array}$

吸光度

$\frac{\mathrm{Cl}^{-}}{\mathrm{NO}_{3}^{-} \mathrm{SCN}^{-}}$

0.021

0.141

0.255

0.517

0.558

$>1.2$

$>1.2$

$>1.2$ マスキング放を最 初に添加しだ場合 洗浄回数

マスキング剂を溶禁相 洗海液中に加元た堨合

\begin{tabular}{cr}
\hline 1 回 & 2 回 \\
0.035 & 0.036 \\
0.142 & 0.145 \\
0.259 & 0.257 \\
0.037 & 0.032 \\
0.302 & 0.271 \\
0.065 & 0.054 \\
- & 0.157 \\
- & 0.285
\end{tabular}

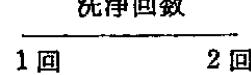

0.033

0.033

0.141

0.142

0.255

0.256

0.038

0.037

0.273

0.261

0.049

0.046

0.154

0.153

$0.258 \quad 0.253$ 
$\mathrm{m} l$ 加えフリマゼ器で 40 秒間的りまぜる。ついで溶媒相洗浄液

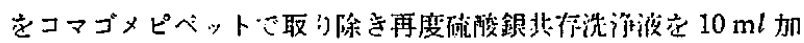

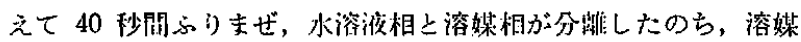
相さ No.3 ガラスフィルターを䎠し水のエマルジョン除志し たの占吸光度灾測定守る。

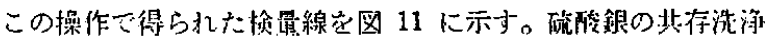

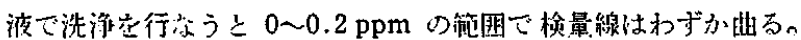

\begin{tabular}{|c|c|c|}
\hline \multirow{2}{*}{$\begin{array}{c}\text { DBS 湠度 } \\
(\mathrm{ppm})\end{array}$} & \multicolumn{2}{|c|}{5 再 現 生 } \\
\hline & 吸光废 ${ }^{a}$ & 標準仳差 \\
\hline 0 & 0.033 & 0.003 \\
\hline 0.1 & 0.043 & 0.004 \\
\hline 0.2 & 0.064 & 0.004 \\
\hline 0.5 & 0.141 & 0.006 \\
\hline 1.0 & 0.255 & 0.012 \\
\hline 2.0 & 0.502 & 0.017 \\
\hline 3.0 & 0.757 & 0.018 \\
\hline 4.0 & 0.998 & 0.021 \\
\hline
\end{tabular}

注 a) 5 回の平均.

\section{4 測 定 実 験}

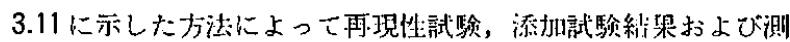
定例袁 $5 ， 6 ， 7$ に示した。

表 6,7 に示与ように隅田川に扔いても再現性よくく定量できた。

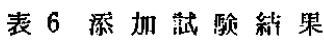

\begin{tabular}{|c|c|c|c|c|c|c|}
\hline 川 & 含有最 & 添加量 & 涮定 & 值（ & $(\mathrm{ppm})$ & 平均 \\
\hline 多整川(风 & 0.44 & 1.0 & 1.53 & 1.47 & 1.50 & 1.50 \\
\hline 隅明川 (千住大橋) & 1.68 & 0.5 & 2.16 & 2.15 & 2.23 & 2.18 \\
\hline & 表 7 & 淑 & 定 & & & \\
\hline 河川名 & 堔 水 & & & 测定 & 值 $(\mathrm{pp}$ & \\
\hline 浅川 No.134 & 1963. 10 & . 14 & 0.1 & & 0.11 & 一 \\
\hline No. 138 & " & & 0.1 & & 0.12 & - \\
\hline 录川（红川市家虚排 & 涾)" & & 2.4 & & 2.51 & 一 \\
\hline 多摩川 (二子) & 1963. 11 & . 16 & 0.3 & & 0.40 & 0.40 \\
\hline 隅田川（千住大橋） & 11 & . 18 & 1.6 & & 1.66 & 1.70 \\
\hline
\end{tabular}

（との報告を“資源科学研究所㮍綃第 1103 号”とする） 